\title{
Pacifism: Equipment or Accessory of War?
}

\author{
Petar Bojanić
}

Received: 1 January 2013 / Accepted: 5 July 2013 /

Published online: 16 July 2013

(C) Springer Science+Business Media Dordrecht 2013

\begin{abstract}
It is my intention to attempt to define pacifism, in its engagement and concept, as a necessary requisite of war and military action, following a phrase used over a hundred years ago by Franz Rosenzweig when speaking of pacifism as "necessary equipment of war." I will try to defend the importance of pacifism as an integral part of war (as such, pacifism as a requisite of war ought to shorten the period of war and mitigate destruction) and oppose this concept of pacifism to Jan Narveson's old attempt at constructing pacifism as a position and then designating it as "untenable and unreasonable," and then further oppose this to his later attempt to find in pacifism the cause of further (and more) violence for ever more vicious wars.
\end{abstract}

Keywords Pacifism $\cdot$ Equipment $\cdot$ Accessory $\cdot$ War $\cdot$ Violence $\cdot$ Prevention

It is my intention to attempt to define pacifism, in its engagement and concept, as a necessary requisite of war and military action, following a phrase used over a hundred years ago by Franz Rosenzweig when speaking of pacifism as "necessary equipment of war" (notwendiges Zubehör des Krieges). I am interested in the role of time in war (does war have its time?, analogously, does peace, much like anything else, "have" it's time?). I would like to examine the "call to peace," or "advocacy of peace" (these phrases are partially synonymous with "pacifism"), and locate them in the time just before the very beginning of war, and at the very end of war. The beginning of war, its duration, and the period following war are essentially "pacified" with various rules and norms ("ius" ad bello, in bello, post bellum), and each of these various periods of conflict has its normative construction and need for its rules to be applied, to change, to succeed one another. It follows from there that the period prior to the beginning of war (ius praeventio) and the period of the end of war, the disengagement (ius ex bello), are characterized with the direct "encounter" of peace and war (war and peace). During the time of entering war (exiting peace) and time entering peace (exiting war), it seems that various forms of pacifism ("calls to peace"), in the broadest sense of the word, dramatically determine the essence of war (bellicism,

P. Bojanić $(\bowtie)$

Institute for Philosophy and Social Theory, University of Belgrade, Belgrade, Serbia

e-mail: bojanicp@gmail.com 
Warism). When I say that pacifism is a "necessary equipment of war," and I locate it in these two periods of development of war, then I am assuming that the following three elements concomitantly call to peace and introduce war (and vice versa): the encounter with the enemy (the other), the individual's or collective's image of the enemy, and the enemy's decision to attack or disengage. "Pacifism," as part or accessory of war, refers above all to locating the beginning and end of war. It is also crucial to explain the importance of the word "necessary" (notwendiges) equipment (and I will shortly suggest a difference between equipment and accessory). Whose decision is war? Is it the enemy (the other) who decides (and if so, how does he decide) on the beginning and end of war?

I want here to defend the importance of pacifism as integral to war. (As a requisite of war, pacifism ought shorten the time of war and mitigate destruction.) In so doing, I oppose this concept of pacifism first to Jan Narveson's initial, 1965 attempt to constitute pacifism as a position that he will then designate as "untenable and unreasonable," and further, oppose it to his latest attempt to find pacifism the cause of (further) violence and ever more cruel wars. ${ }^{1}$ (It seems to me that unwittingly, Narveson here repeats Schmitt's critique of Kant's term of preventive war and unjust enemy. ${ }^{2}$ Further on I will explain more closely how the "call to peace" functions imminently before the beginning of war (ius praeventio).

Two or three fragments that I am about to quote, extracted from so-called marginal, pseudo-texts (archives, correspondences, interviews, etc.) could show, above all, that peace (the beginning or termination of war) is always decided upon by the other (the adversary or enemy). The difficulty with peace and pacifism, really with the beginning or termination of war, is always about the fiction of the ultimate enemy and our total destruction at his hand. ${ }^{3}$ In 1965, Julien Freund, friend, student, and translator of Carl Schmitt, is defending his doctoral thesis, L'Essence du politique [The Essence of the Political], before a committee including Raymond Aron, his mentor, as well as Raymond Polin, Paul Ricoeur, and Jean Hyppolite. Freund writes about the debate with Hyppolite in his 1991 book of interviews:

“Thus arrives the moment of Hyppolite's intervention. He had acknowledged my work by adopting Aron's arms; he found me too severe against Kelsen but then settled on our fundamental difference, the source of his refusal. " Reste la

\footnotetext{
${ }^{1}$ I will select three out of any number of texts by Narveson: J. Narveson, "Pacifism: A Philosophical Analysis", Ethics, vol. 75, n. 4, Jul. 1965, 259-271; J. Narveson, “Is Pacifism Consistent?”, Ethics, Vol. 78, n. 2, Jan. 1968, 148-150; "Is Pacifism Reasonable?", as well his lecture given on 21 June 2012 in Belgrade, at the Institute for Philosophy and Social Theory. On the last page of the manuscript in the text "Is Pacifism Reasonable?", Narveson writes: "That is why pacifism is fundamentally unreasonable, despite - or rather, because of - the eminently reasonable preference of peace to war. It is unreasonable because, given the way people generally are, it ordains the very asymmetries that invite and cause wars." Narveson here actually restates an obscure comment in Machiavelli (but which can also be found elsewhere), who reproaches the pacifist that his refusal to preventively react to violence produces much larger damage and the impossibility to react further on. "Pacifism should be morally condemned because in refusing to use force to prevent the ruin of some, it allows the ruin of all." D. R. Mapel, "Realism and the Ethics of War and Peace", ed. T. Nardin, The Ethics of War and Peace, Princeton, Princeton University Press, 1996, 57.

${ }^{2}$ Carl Schmitt analyzes several fragments by Kant on war, chiefly $\S 60$ of the book Metaphysics of Morals. C. Schmitt, The Nomos of the Earth, New York, Telos Press, 2003, "Kant's Unjust Enemy”, 168-171.

3 "Enmity is the total negation of another being in its complete life action." (Feindschaft ist die totale Negation des anderen Seins in allen seinen Lebensbetätigungen), E. Husserl, E III 8, 1934, 12.
} 
catégorie de l'ami-ennemi définissant la politique. Si vous avez vraiment raison, a-t-il affirmé, il ne me reste plus qu'à cultiver mon jardin. " ("There remains the category of friend-foe, politically defined. If you are truly correct, he said, nothing is left for me but to cultivate my own garden.") To which I said: "Listen, Mr. Hyppolite, you have said two or three times recently that you were wrong about Kelsen. I believe you are about to make another mistake, because, like all pacifists, you think that it is up to you to designate the enemy (car vous penser que c'est vous qui désignez l'ennemi, comme tous les pacifistes). But, you see, the moment we no longer wish to have enemies, we will not have them ( $D u$ moment que nous ne voulons pas d'ennemis, nous n'en aurons pas, raisonnez-vous). Rather, it is the enemy who designates you as such (Or c'est l'ennemi qui vous désigne). And if he wishes to be your enemy, you can treat him as friendly as you like. From the moment he wishes you to be his enemy, you indeed are such. And he will even prevent you from cultivating your garden." (Et s'il veut que vous soyez son ennemi, vous pouvez lui faire les plus belles protestations d'amitié. Du moment qu'il veut que vous soyez l'ennemi, vous l'êtes. Et il lvous empêchera même de cultiver votre jardin). To terrible effect (Tragique même), because Hyppolite retorted: "In which case, there is nothing for me to do but commit suicide." (« Résultat : il ne me reste plus qu'à me suicider »). ${ }^{4}$

Franz Rosenzweig's original contribution to histories of war and pacifism, or suggestion for the resolution of the "pacifist dilemma," can be found at the end of a letter to his parents from January 6th, 1917. Imminently after the official offer of peace by Wilhelm II (on December 12th, 1916), Rosenzweig writes that only then was it clear to him what pacifism was:

Pacifism is in fact - this has become clear to me in the past days, since the 12th necessary equipment of war (notwendiges Zubehör des Krieges). So, war is not lead in order to force (zwingen) the enemy (Gegner) - it would be impossible for that to last long - but to subjugate (unterwerfen), to impose (aufzuzwingen) on him one's own will, to replace (ersetzen) his will with mine. The victor does not wish to make a tool (Werkzeug) of the vanquished (because he cannot persevere in it), but rather his slave. The goal of the victor is not the destruction of the enemy (Vernichtung des Feindes), but the basing of a new contract. But this supposes that in the enemy there is a shred of a "desire for peace," (Friedenssehnsucht) which has fallen asleep, and the mission of the war is to awaken this desire. If this desire for "peace at all cost" (Frieden um jeden Preis) becomes stronger than the ability to suffer (Heroism), then the hour of peace has struck. All this of course applies to two victors as it does to one. Therefore pacifism is "as old as" war (namely, human, slave-directed war (Versklavung gerichtete Krieg); animals only know a war of destruction (Vernichtungskrieg), and hence have no pacifism). $-\ldots 5$

\footnotetext{
${ }^{4}$ J. Freund, L'aventure du politique, Paris, Criterion, 1991, 45.

5 "F. Rosenzweig an die Eltern," 6 January 1917, F. Rosenzweig, Der Mensch und sein Werk, 1. Briefe und Tagebücher, Haag, Martinus Nijhoff, 1979, Vol. 1, 327-328.
} 
Essentially, there is no new content or new rhetorical strategy in these endlessly interesting fragments. Hyppolite is not original, but his position does in one way or another lead to the termination of violence or war by abolishing their possibility (there is no confrontation with the other, the one who designates me as his enemy; it is utterly unclear why a pacifist position would imply suicide, that is, violence towards oneself). ${ }^{6}$ Similarly with Rosenzweig: his argument - that war (or violence) ought to force or awaken the "desire for peace" in the enemy (Friedenssehnsucht), in order for a new truce to be implemented (a contract; new right), making all sides in the war victors from that moment - represents no particular discovery in the histories of violence and negotiations. What I do think is precious in Schmitt and Rosenzweig (each of them is anti-pacifist in his own way, just as Narveson) is the very precise identification of the crucial point in time ("the culmination of war") at which the problem of peace, or beginning of war, or end of conflict is resolved. Paradoxically, the place of beginning and end (or termination) of war is to be found in the enemy, or in our fictitious strategies of the enemy element, either way, marking our Western concept of time. If Schmitt (or Freund), along with Kant, assumes an unfair enemy, with whom no negotiating is possible, who initiates war by designating us as enemy, Rosenzweig, on the other hand, writes about the duration of war, when that same unfairness and unreasonableness of the enemy is still present, and when it is still impossible to come to an agreement with him. When the enemy does finally "call to peace" or agrees to it, when he actually utters what I keep saying (and "his will [is] replaced with mine"), ${ }^{7}$ when he, in one way or another, becomes "pacifist" - this is the point of this whole construction - then all sides are victorious, and the passage from war to peace is ensured. The cunning embedded in the refutation of pacifism, from Kant, through Schmitt, to both the early, 1965 Narveson and the latter one, from $2012^{8}$ (the possible monstrosity of this list of names, the mix of conservatism, quasi national socialism, and liberalism, has not escaped me either), is in the measuring out of aggression and evil in an enemy, more specifically, enemy X, who out of nowhere, suddenly, and usually with no reason whatsoever, attacks (which is one of the standard conceptions of the evil principle, is it not?). There is a terrifying collective fantasy, active and widespread in the last ten years as it was when Narveson first formulated his theory, according to which we are, each and every one, in a latent war against a merciless, attacking enemy

\footnotetext{
${ }^{6}$ The argument that a possible pacifist position presupposes life as absolute value is inadequate, since this value is even more so implicit in the position that demands response to violence and defense (of that life) from violent attack.

${ }^{7}$ With this move, Rosenzweig restores the concept of heroism, repeating a well known line from Avot de Rabbi Natan 23: "Who is a hero among heroes? He who controls his urge, and he who makes of his enemy his friend." Cf. R. Kimelman, "Non-Violence in the Talmud”, Judaism, Vol. 17, n. 3, 1968, 320.

${ }^{8}$ Developing on the 1965 text, Narveson's 2012 work classified and mitigated certain leaps and complications. The 1965 Narveson is grappling with the popular, but also radical, contradictory and incoherent nature of pacifism ("confusion is probably what accounts for such popularity as pacifism has had" [259]), attempting to show how unprincipled and untenable it is as a moral position ("the pacifist's central position is untenable" [271]). This year, however, completely tangentially and arbitrarily, Narveson sifts through his old text, editing it to enhance it with breaks and readability. This time around, however, he is interested in the responsibility of pacifism for the enlargement of violence in the world.
} 
(one who cannot, in Rosenzweig's fashion, be converted into a friend). ${ }^{9}$ This fantasy ought to produce and imply the position of one who steadfastly refuses to oppose such aggressive and extreme violence. (It is important to note, each and every one is under threat at the same time, whereas death strikes only individually and at various times. And lest we forget, 1965 is a year of unrest, with draft notices arriving, American military expeditions becoming ever more common in Vietnam and lasting nearly twenty years. ${ }^{10}$ There follow, in this theory, two further steps: completely unwarranted, this passive position acquires the name "pacifist," meaningless and irrational, since non-resistance to the specter of communism or terrorism is capitulation in advance, bringing only greater damage in the future, i.e. more violence and destruction. In other words, "the evil" of physical violence that a pacifist (or pacifists) would commit, the "substantive evil" that could result from his individual use of violence, is negligible in comparison to the size of the evil we are, each individually and all together, required to oppose.

Here then, immediately, two explanations. (a) Each of us individually ought to wonder when and whether one has ever been attacked in such an extreme fashion? Furthermore, why should passivity, or endurance, or response be the paradigmatic problem stemming from this potential attack? And is that the most important question to come out of violence and wars? Why should the question (and answer) of our response to some violence (always hypothetical and imaginary, quite rare today) be what determines us, and then potentially define us as pacifists? Is, analogously, the position of bellicist or "warrist" defined by a force that retaliates disproportionately stronger to the initial violence? In other words, in searching for the most philosophical of moments within the "darkness of irrationality" of pacifism, why should we, for example, suspend the activity of the pacifist in the processes of prevention and reduction of conflicts within institutions? Is it really the case that among those doctrines known as "pacifism," "only the doctrine that everyone ought not to resist violence with force is of philosophical interest"? ${ }^{12}$ And anyway, what is the origin of this reduction of pacifism, such as Narveson conducts it (followed by others)? ${ }^{13}$ Recall that in his 1965 text, Narveson imagines in several places all the various answers and explanations the pacifist has to give. He forces, only to immediately disregard as untenable, a position that would

\footnotetext{
${ }^{9}$ In 1758, Vattel calls these enemies "the disturbers of peace" (des perturbateurs de la paix), the most cruel enemies of human kind (les cruels ennemis du genre humain), who must be opposed and destroyed. E. Vattel, Traité du droit des gens, Paris, Edition Aillaud, 1835, book IV, § 1. In his Lectures on Moral Philosophy of 1784 Kant claims that a just war against such an enemy is never terminated (Jus belli contra hostem injustum est infinitum). I. Kant, Vorlesungen über Moralphilosophie, Vol. 4, Berlin, Walter de Grunter, 1979, 1372.

${ }^{10}$ In order to scare the poor pacifist, the 1965 Narveson introduces Nazis, or rather, "some of the SS men" who supposedly experimented with victims in order to find the moment when enduring violence turns into resistance. J. Narveson, "Pacifism: A Philosophical Analysis," 263.

11 "Nobody thinks that we have a right to inflict pain wantonly on other people. The pacifist goes a very long step further. His belief is not only that violence is evil but that it is morally wrong to use force to resist, punish, or prevent violence." J. Narveson, "Pacifism: A Philosophical Analysis", 259.

12 J. Narveson, "Pacifism: A Philosophical Analysis", 260.

13 "Some people believe that it is never morally permissible to use force against another person. This position is usually described as pacifism. A committed pacifist will think that even when one's own life is threatened by a murderous attacker, morality does not permit one to use to prevent that attack. Nor can one use force to defend other people's lives. More people are not pacifists." H. Frowe, The Ethics of War and Peace. An Introduction, London, New York, Routledge, 2011, 9.
} 
best fit minor Christian fantasists from the beginning of the 19th century claiming that war is inconsistent with "the Religion of Jesus Christ," or Tolstoy, ${ }^{14}$ or doctrines of the first "Non-Resistance Societies" in England and the USA. ${ }^{15}$ Arguments against such a caricatural and theatrical simplification of the "pacifist position" ought to emphasize not only the stronger and better characteristics of pacifism, the ones less interesting to philosophers who use a technique of cross-examination to refute everything they themselves construct, but also certain facts, which, as we know, did not and do not interest Narveson. If there are significantly fewer attacks on individuals or groups today than 47 or two hundred years ago, certainly a consequence of the general pacification of the world and various preventive activities of those who cannot be called militarist, then the question of philosophic interest is not whether the pacifist (or the pacifist position) can be detected in one's answer to an attack and one's treatment of those attempting murder. Rather, it is whether there is (or why there is not?) any benefit in attacking and committing violence? In other words, what form does violence have to take for the consequence to be a clear public benefit? (For example: preventing violence that precedes this new violence - here I mention the minimal goal always dear to those who dislike violence and wish to see it forever abandoned through one last war or one last violent preventive coup. $)^{16}$ If I remove the messianic moment from this last question (certainly this maximalism is regulative, and can be found not only in Rosenzweig but Narveson himself), I cannot but point out that the activity and position of the pacifist are better explained by the suspicion that violence or war can in fact be (not only morally) justified (but practically acceptable - use of violence does not usually accomplish a given goal), or that either can achieve significant results. Before throwing the pacifist to the aggressor, to see whether he would rather suffer than turn resistant, it seems to me that Narveson ought to have questioned the meaning of the attack as such, and the meaning of the use of violence in general. I do not consider it philosophically meaningless to take the perspective in which the pacifist, before responding to the violence befallen him or one close to him (or one innocent and defenseless), remains surprised by the very existence of violence as such (to what end?), and then feels responsible for that same violence, not having done enough to prevent and abolish it. Nor do I believe that it proves that I am a pacifist if I decline to say wether I would thwart or shoot at a certain Adam Lanza, who opened fire at children, teachers, and parents in a school in Newtown, Connecticut. My problem is that I am responsible for this terrible violence, not least because his mother, who was among his victims, had no qualms about possessing an

\footnotetext{
14 "The next kind of war to be considered is the war of self-defense. This kind of war is almost universally admitted to be justifiable, and is condemned only by Christ and Tolstoy." B. Russell, "The Ethics of War," International Journal of Ethics, Vol. 25, n. 2, 1915, 138.

${ }^{15}$ It is relatively ease to show that Narveson's construction of the main characteristics of the pacifist or the pacifist position has little to do with either Bertrand Russell (Narveson mentions him towards the end of his 2012 text and underscores his change of position in World War II) or Gandhi's thoughts on non-violence. Lest we forget, Gandhi too advocated going to war and defending the British Empire: "The theory of nonviolence is a complex theory: we are mortal, fragile (defenseless) beings, inducted into violence (himsa). The saying "life lives life" is laden with meaning, as man can live not a single moment and not, consciously or unconsciously, commit violence. The very fact that he is alive - that he eats, drinks, moves - necessarily implies himsa..." M. K. Gandhi, My Life for Freedom, (1925), quoted in D. Losurdo, La non-violenza. Una storia fuori dal mito, Laterza, Bari, 2010, 33.

${ }^{16}$ Narveson will certainly have to further explain somewhere the following sentence from this year's text, which does not look entirely convincing: "We can benefit from violence, unfortunately, where that violence is unilateral" (last page of the manuscript).
} 
arms collection, etc. It would be interesting to show that even those who do not know that these shootings occurred, or have not heard of the second amendment, Dostoyevsky, Emmanuel Levinas, or even those who understand nothing nor empathize with the victims - even they are still a priori responsible. The existence of violence or war presents the ever problematic concept of collective or group responsibility, whereas pacifist action necessarily implies a common engagement against violence or war, and not exclusively individual, such as Narveson would have it.

(b) Naturally, I do not believe that the smaller number of attacks and aggressions, "instances of violence" in general, especially in the last few decades and only in certain parts of the globe (not all, of course), is entirely a consequence of various pacifist actions and engagements, nor would I equate pacifism with tactics ${ }^{17}$ or ideal activism that ought to ultimately manifest in an absolute referendum of all for a "preference for peace." At the very end of the text "Is Pacifism Reasonable?" Narveson writes:

We must, alas, be able to make war if we can't have peace. When everybody shares the preference for peace, then we can scale down and hopefully eventually eliminate war-making capability. Until then, however, pacifism is a nonoption in the near run.

I do not think we need a special kind of waiting and looking into the future, nor is this pathetic and inadequate maximalism necessary - the idea that we must all together, en bloc, "decide" on peace and share a collective intentionality of never doing anything violent. It is enough to inch the words "peace," "preference for peace," and "pacifism" towards our ability to conduct war, something Narveson defines very well. The idea that wars can be conducted in various ways, that there are just and unjust wars, mandatory wars, permitted, discretionary wars, ${ }^{18}$ as well as prohibited wars, and that wars of aggression are not justified (in part too because they have a small chance of being victorious) - all these possibilities show that the pacifist position (or pacifist engagement) has a long history of being already built into our understanding and theory of war. ${ }^{19}$ Precisely the justifying of the (accompanying but

\footnotetext{
${ }_{17}$ J. Narveson, "Pacifism: A Philosophical Analysis", 263.

${ }^{18}$ Let me leave aside two complicated arguments regarding the difference between mandatory wars (commanded, of obligation) (milhemet mitzvah or milhemet hovah) and discretionary wars (milhemet reshut) in relation of the status of preventive war and the "place" which peace or pacifism occupied within those (for example, do all types of war imply that one ought to be "offering peace first?") Cf. M. Walzer, "War and Peace in the Jewish Tradition", ed. T. Nardin, The Ethics of War and Peace, Princeton, Princeton University Press, 1996, 101; D. Bleich, "Pre-emptive War in Jewish Law", Tradition, Vol. 21, n. 1, Spring 1983, New York, 3-41.

${ }^{19}$ In the book Der Genius des Krieges und der Deutsche Krieg (Verlag der Weißen Bücher, Leipzig, 1915), Max Scheler conducts one of the first detailed thematizations of the difference between just and unjust war ("Der gerechte und ungerechte Krieg" (153-161)). This fragment also contains one of the first detailed arguments about the injustice of preventive war since Grotius. I only mention this book in this place because of a lecture (and a short book that followed) given in January 1927, at the Reichswehr Ministry, Die Idee des Friedens und der Pazifismus, published posthumously in Berlin in 1931 (Der Neue Geist Verlag). In chapter 4, Scheler shows that there is not only one pacifism, but rather many, and that he has been able to identify eight different types of pacifism: individual heroic pacifism, Christian pacifism, liberal economic pacifism, legal pacifism, communist and socialist-Marxist semi-pacifism, imperialist hegemonic pacifism, international class pacifism of big capital bourgeoisie, and cultural pacifism (cosmopolitanism). Pacifism, which he rejects as a position, serves Scheler to modify Romantic militarism from the time of World War I.
} 
always conspicuous) place of pacifism within the war machine, it seems to me, could ensure the activity and activism of the pacifist position. In any case, this is the position throughout the history of wars that pacifism was recognized to have had, which was an important element in the reduction of speed of war activities.

But, how do we now locate with precision pacifism within militarism and war? Would that be the clear and resounding call to peace of an armed and alert man (certainly ready to kill, to defend, to attack)? How do we levy Rosenzweig's idea of pacifism as accessory and equipment for war (or warrior), as an alternative to Narveson's or Scheler's difficulties to thematize a specific pacifist position? What would it mean to put war in its holster (peace), to add to war something minimal (a call to peace which negates and affirms it at the same time), technically equip war and contain it (equipment can be the protective, but also the hindering, preventive frame), and at the same time preserve and not abandon the very presupposition and perspective of peace?

For the fiction of the grandiose perturber of peace to be in some sense lessened and pacified, I would suggest a construction in which the basic function of pacifism as equipment of war is discovered (a) before war and violence - in the space of preventive law and preventive force (aggression and unjustified preemptive attack and preventive war would thus potentially be mitigated), and (b) at the very end of war, when active coercion, but also the incessant call to peace, awakens the desire for peace in the enemy.

Let me briefly sketch out the pacifist's "position" in the period prior to war's beginning, introducing a few preliminary elements, and attempting to further elucidate Rosenzweig's suggestion regarding the proximity of war and pacifism.

First, Rosenzweig's word das Zubehör can be translated both as equipment and accessory. To begin with, I would designate the first word as a part without which something cannot function. The latter designates an addition that enhances or slightly changes the function of something, but does not determine it, nor is its integral part (An iPad need not have an external disk or a cover, just as a crime need not necessarily have an accomplice). My assumption is that the "presence" of peace (or demand for peace) changes and varies throughout the various periods of war. Pacifism is thus sometimes equipment and sometimes accessory. However, this same "presence" (or insistence on peace) is most present before war's beginning, that is, in anticipation of war, and then again at war's end, when peace is on the horizon. It is in these two periods that pacifism is the "necessary equipment of war." Second, since the pacifist's voice is strongest at the beginning and end of war, my understanding of peace will necessarily determine the main characteristic of pacifism. This corresponds to my somewhat trivial designation that war "contains" the most peace before its beginning and before its end - we are here in the domain of acts which initiate war, as well as terminate war, or initiate peace. The construction and understanding of peace, implies the basic characteristic of the pacifist position, that is, the way "the call to peace" functions at war's beginning and end. Let me quote a passage from Kelsen about peace and law:

Peace is condition in which there is no use of force. In this sense of word, the law provides only relative peace, in that it deprives the individual of the right to employ force but reserves it to the community. The peace of the law is not a state of absolute absence of force, a state of anarchy, but rather is a state of a monopoly of force, a monopoly of force by the community. ${ }^{20}$

$\overline{{ }^{20}}$ H. Kelsen, Law and Peace in International Relations, Cambridge, Harvard University Press, 1942, 12. 
Kelsen's, shall we say rather imprecisely, contingent determination of peace, which is de facto constantly muddied by the potential or preventive and actual force of the state or states (the state opposes different occasional uses of violence and force, which Kelsen terms "anarchism"), could have a corresponding contingent pacifism. Third, the characteristic of this pacifist position is not based on an imprecise differentiation of violence and war (where war can never be justified, whereas punishing a crime or self-defense can in certain cases), but rather on the trust in a certain, so-called, professional use of violence. This means that there is a certain violence which can be regulated, and can be justified, because it is capable of stopping or reducing some other future violence. This violence would be professional not only because it would efficiently stop violence, preventively or post festum, but also because it would at the same time abandon its own action and force, and remove any kind of benefit from violence. The only "benefit" of violence we could have is either that there be no violence or that it be stopped quickly.

The fourth preliminary element, perfectly built into any position which could be characterized as pacifist, regards the epistemological value of violence and war. The function of pacifism as a necessary equipment of war is not only the stopping or retarding preventive moves, preventing a response to violence or, perhaps, accelerating and forcing violence which could end some other violence more quickly. Pacifism's function can be also, and above all, comparing facts, causes and effects of various kinds of violence. We do not know whether there will be an attack, nor whether our preventive action will actually prevent a planned attack, nor whether a response to violence will reduce a certain future violence. If we do not know, if the status of the statements of future is completely uncertain, ${ }^{21}$ any acceleration (the basic characteristic of the war machine) represents aggression, immorality, ${ }^{22}$ and what is more, stupidity.

This ignorance or impossibility of knowing whether the "Bad Things" will indeed happen shortly, the uncertainty of necessity of preemptive attack (a "response" to immanent attack) or preventive war ("guerre de précaution") in order to prevent these "Bad Things," have all been cunningly placed in the background throughout the histories of justification of violence. The strongest possible construction that is supposed to remove facts and waiting as a "legitimate method of verification," and which justifies the preventive intervention, is at the same time, paradoxically, the best argument against pacifism. Namely, one who thinks preventive measures unjustified (i.e. aggressive, and thus forbidden) is a pacifist. As I already mentioned, Narveson's key argument against pacifism, from first to last text, consists in the justification of the use of preventive force as a response to a smaller evil, in order to avoid a greater evil (There are then, always

\footnotetext{
${ }^{21}$ The statements about the future are really only about the present. “(...) we have pointed out from the beginning that our definition of meaning does not imply such absurd consequences, and when someone asked, 'But how can you verify a proposition about a future event?', we replied, 'Why for instance, by waiting for it to happen! "Waiting" is a perfectly legitimate method of verification." These words by Moritz Schlick from 1934 are quoted in D. Haldcroft, "Schlick and the Verification Theory of Meaning", in Revue international de philosophie, n. 144-145, 1983, 58.

22 "If we don't know, then what we are doing is immoral". H. Putnam, "The Epistemology of Unjust War", in Philosophy in an Age of Science, ed. M. De Caro \& D. Macarthur, Cambridge, Harvard University Press, 2012, 318. Here is Putnam's presentation of her colleague, Roderick Firth's argument: "Both of Firth's principles employ the notion of "knowledge." According to the principles, justification of war requires that we know that the Bad Things will not happen if we resort to war (resort to maiming and killing) and that we know that the Bad Things will not continue (or be replaced by even worse Bad Things) if we do resort to war." 319 .
} 
things worse than bad). ${ }^{23}$ Since the pacifist refuses to answer violence in kind, she is thus indirectly responsible (here Narveson's formulation is stronger - "morally condemned") for the continued existence of violence and ever more vicious wars. We can see the origin of this phrase "more violence" 24 or "greater violence" in a definition that brilliantly elucidates Narveson's intent: "In prevention, violence is simply considered as a means for reducing greater violence." 25 Whence the idea of "greater violence" or "greater evil" in the context of an action that has as its intent the stopping, in a given time, a threat or danger? Undoubtedly we are dealing with a metaphor that has entered the language of modern politics from medical strategies, which can be seen in various constructions for and against preventive action, from Gentili and Grotius to Kant, in which this option is mentioned in a different context only once. However, precisely this moment ought to show that this supposition of greater evil and the preventive action that interrupts it indirectly or delays it infinitely, belongs to the pacifist register of introduction to a just war. Prior to Frederick of Prussia who mentions this strategy explicitly, and which Kant notes in his lectures and in $\S 56$ i $\S 60$ of Metaphysics of Morals (when talking about excessive arming by a state and jus praeventionis), preventive war or a preventive act is: a) an action, an attack which is a defense, and not a reaction or response to violence; b) a symmetrical act - Gentili and Grotius use the metaphor of the gladiator, an either-or situation (either kill or be killed, hence "better to intercept than be intercepted") ${ }^{26}$; c) further, fear of attack or "just fear" ("just fear is defined as the fear of a greater evil (timor maioris malitatis)") is sufficient justification for a preventive attack (in this context Gentili quotes Philo's (Judaeus): "[an] excellent saying, that we kill a snake as soon as we see one, even though it has not injured us and will perhaps not harm us. For those we protect ourselves before it attacks us") $)^{27}$; d) "just fear" becomes "legal fear" for Francis Bacon; fear transforms preventive into defensive war; e) preventive war serves to prevent destruction (Montesquieu, Machiavelli); f) a prevention of evil to come (future mali) (Hobbes, Pufendorf); g) to be quicker and getting in first (Hobbes), etc. The novelty in Frederick of Prussia is when he differentiates among several kinds of war and justifies preventive wars (les guerres précaution), "which princes would do well to undertake:"

They are really wars of aggression, but not less just for it. When the excessive strength of a power seems ready to spill over and threatens to envelop the universe,

\footnotetext{
$\overline{23}$ "I tried to insist that the justification of the use of preventive force if necessary was built into the very concept of a right itself." J. Narveson, "Is Pacifism Consistent?" 149. "It seems to me logically true, on any moral theory whatever, that the lesser evil must be preferred to the greater. If the use of physical force by me, now, is necessary to avoid the use of more physical force (by others, perhaps) later, then to say that physical force is the supreme (kind of) evil is precisely to say that under these circumstances I am committed to the use of physical force." 148.

24 Towards the beginning of his manuscript from 2012, article 4, Narveson begins his sentence thus: "If using violence at $\mathrm{t} 1$ would prevent more violence..."

${ }^{25}$ J. Babic, "Pacifizam," Srpska politicka misao, n. 2-3, 1995, 267. (in Serbian). A similar formulation can be found in J. Babic, "Pacifism: Is Its Moral Foundation Possible or Needed?" ed. A. Pavkovic, Contemporary Yugoslav Philosophy: The Analytic Approach, Dordrecht/Boston/London, Kluwer Academic Publishers, 1988, p. 58.

26 "C'est une maxime certain qu'il vaut mieux prévenir que d'être prévenu" (It is doubtless a good principle that it is better to intercept than be intercepted). Frederick II, King of Prussia, L'Antimachiavel, (1740), Oeuvres philosophiques, Paris, Fayard, 1985, 130.

27 A. Gentili, De Iure Belli Libri Tres, (1612), Vol. 2, London, Oxford, 1933, 61-62. Gentili announces that he will speak of "greater evil" in a different place, but does not. 63 .
} 
it is wise, while one is still in control, to set up a barrier against it, to stop the tempestuous course of a flood. One sees a storm brewing which he cannot dispel alone: thus he joins with those who are united by a common danger into a single interest. Had the kings of Egypt, Syria, and Macedonia banded together against the Roman power, the latter would never had been able to disrupt them; a wisely planned alliance and a war undertaken on time would have avoided ambitious plans, the execution of which would see the whole universe in chains.

It is prudent to favor the smaller evils over the greater ones, just as it is to choose that which is most safe to that which is uncertain. It is better, then, for a prince to engage in an offensive war while still in control of the olive branch and the laurel branch, than to wait for desperate times or a declaration of war that could delay his slavery and ruin by no more than a few moments. ${ }^{28}$

The fantasy of "the great evil," apart from not having time for decisions and the action it produces ad hoc, evidently also assumes the urgent unity of all in order to prevent the constituting of the big "Bad Thing." The potential opposition and protection from a future "great evil" or "greater violence," implies the engagement of multiple actors or the general engagement of all for the removal of the presently urgent problem. Of course, it is insufficient to systematically correct Narveson's obsession (and that of others) regarding "unilateral" acts of violence (and response to them), and convert the singular, "pacifist" into the plural, "pacifists." Nor is it sufficient to consistently show that not opposing violence also implies a form of collective engagement, which can in certain cases be very successful in isolating violence and preventing it from becoming "great." It is also unnecessary, I think, to explain that if I shoot Adam Lanza in the back, after him shooting his first few victims in a Newtown, Connecticut school and after his refusal to put down his weapon, this does not at all mean that I am not a pacifist, since I have just become preventor, thus averting further evil and more people becoming victims. Prevention is not to be found in this place, just as a potential preventive act of the state of Connecticut against individuals who are armed and frantically arming themselves (gun sales have dramatically increased since the terrifying crime at the school) will not bring peace other than the one described by Kelsen. I would suggest, however, that my initial call to peace and laying down of weapons by Adam Lanza be a basic example of Rosenzweig's suggestion of pacifism as a "necessary equipment of war." 29 Of course, the timing of this call, the time limit, the duration of the interval, the waiting and hesitation of the actors, as well as, finally, the readiness for violence to be committed in a professional manner, will decide not only whether pacifism is equipment or accessory of war (or violence), but also whether violence needs to be further prolonged.

\footnotetext{
${ }^{28}$ Frederick II, King of Prussia, L'Antimachiavel, 129-130.

29 The paradigm and key to Rosenzweig's idea can certainly be found in Deuteronomy 20:10-11. Here is a fragment of Luzzatto's comment quoted by Michael Walzer: "But it seems to me that in the beginning of this section (20:1), in saying "When thou goest forth to battle against thine enemy," Scripture is determining that we may make war only against our enemies. The term "enemy" refers only to one who wrongs us; hence Scripture is speaking only of one invader who enters our domain in order to take our land and despoil us. Then we are to wage war against him - offering peace first." Cf. M. Walzer, "War and Peace in the Jewish Tradition", ed. T. Nardin, The Ethics of War and Peace, 101. Rivon Kygier writes about the disagreement in interpretation of this passage and the Nachmanides critique of Rachi's interpretation in "L'interpretation rabbinique du commandement d'anathème sous la conquête de Canaan", Pardès, n. 36, Paris, 2004, 67-70.
} 